\title{
Some effects of rumen ciliate protozoa in cattle given restricted amounts of a barley diet
}

\author{
By F. G. WHITELAW, J. MARGARET EADIE, \\ S. O. MANN AND R. S. REID \\ Rowett Research Institute, Bucksburn, Aberdeen $A B_{2}{ }_{9} S B$ \\ (Received 197 fuly 1971 - Accepted 13 September 1971)
}

\begin{abstract}
I. Two pairs of Friesian steers were changed from ad lib. to restricted intake of a pelleted barley diet and were maintained on this latter intake for periods of 18 or 25 weeks. The restricted level of intake was $70 \mathrm{~g} / \mathrm{kg}^{0.73}$ and was adjusted weekly according to individual live weights. The daily allowance was given in three equal feeds during day-time.

2. After an initial period of 9 weeks on the restricted diet, during which all four animals were kept free of rumen ciliate protozoa, one member of each pair was given an inoculum of rumen ciliates. Eight weeks later, the ciliate-free member of the younger pair of steers was similarly inoculated. Observations were made on the rumen bacterial and protozoal populations and on changes in rumen $\mathrm{pH}$ and volatile fatty acids (VFA) throughout each treatment period. The concentrations of urea and haemoglobin in blood and of glucose and amino acids in plasma were examined on one occasion in each animal.

3. In the absence of ciliates, restriction of intake resulted in rumen $\mathrm{pH}$ values and molar proportions of VFA similat to those normally encountered on an ad lib. intake of a barley diet. A decrease in bacterial numbers and certain minor changes in bacterial types were observed on changing from $a d \mathrm{lib}$. to restricted intake but the resultant population under ciliate-free conditions was basically the same as that found later in the faunated animals. In culture, organisms of the genus Bacteroides were predominant.

4. Large populations of rumen ciliates were established in each animal inoculated. Relative to the ciliate-free periods, the presence of ciliates resulted in an increase in rumen $\mathrm{pH}$, a reduction in total VFA concentration and a decrease in the ratio of propionic to butyric acid in rumen fluid. It is concluded that these changes are a direct effect of ciliate activity.

5. Conditions within the rumen remained more stable from day to day when large ciliate populations were present than when ciliates were absent. In one animal, spontaneous fluctuations in ciliate number were accompanied by corresponding changes in rumen $\mathrm{pH}$ and VFA proportions.

6. Significant differences were observed between faunated and ciliate-free animals in the concentration of urea in blood and of glucose in plasma; only minor differences were noted in blood haemoglobin and plasma amino acid concentrations.
\end{abstract}

Some of the changes in rumen fermentation pattern and microbial population which can be induced by alteration of the quantity of a pelleted barley ration given to cattle have been examined by Eadie, Hyldgaard-Jensen, Mann, Reid \& Whitelaw (I970). In that work it was shown that a low ratio of propionic to butyric acid in the rumen fluid was associated with the development of a particularly large population of rumen ciliates in animals given the barley diet at various levels of intake below appetite. The restriction of the diet per se appeared also to have some effect on the rumen fermentation pattern but this was not examined in detail.

The object of the present work was to compare rumen conditions in ciliate-free steers given the restricted barley diet with those in similar animals in which a ciliate population was initiated by inoculation. A brief account of these experiments has been published (Eadie \& Mann, 1970). 
EX PERIMIENT AL

Animals and management. Two pairs of unrelated Friesian steers were used. One pair $\left(8_{57}, 858\right)$ was I4 months of age and had a mean live weight of $474 \mathrm{~kg}$ at the start of the experiment; the other pair $(977,991)$ was 7 months of age and had a mean live weight of $275 \mathrm{~kg}$. All four animals had previously received a high-starch diet ad lib. and each was fitted with a rumen cannula at the start of the present experiments. The animals were penned individually within the same building but the pens were sufficiently far apart to prevent aerial contamination between the faunated and ciliatefree members of each pair. Care was taken to prevent transfer of ciliates to the ciliate-free animals. Sawdust was used as bedding.

The diet consisted of a pelleted concentrate mixture containing $85 \%$ barley and I $5 \%$ protein-mineral-vitamin supplement and was identical to that used by Eadie et al. (1970). After a preliminary period of $a d l i b$. feeding (period I) during which the rumen cannulas were inserted, the ration was restricted and was given in three equal feeds at $08.00,14.00$ and 22.00 hours each day (period 2). In period 3 one member of each pair $(857,977)$ was given an inoculum of ciliate protozoa and in period 4 the ciliate-free member of the younger pair of steers (99I) was similarly inoculated. The nature of the various treatments and the duration of each period are indicated in Table $\mathbf{I}$.

Table I. Sequence and duration of ad lib., 'restricted' and 'restricted plus ciliate' treatment periods

\begin{tabular}{lllrc} 
& \multicolumn{3}{c}{} \\
Steer no. & \multicolumn{1}{c}{ I } & 2 & \multicolumn{1}{c}{ Period } & 4 \\
857 & ad lib. (7) & $\mathrm{R}(9)$ & $\mathrm{R}+\mathrm{C}(9)$ & - \\
858 & ad lib. (7) & $\mathrm{R}(9)$ & $\mathrm{R}(9)$ & $-\overline{\mathrm{C}}(8)$ \\
977 & ad lib. (8) & $\mathrm{R}(9)$ & $\mathrm{R}+\mathrm{C}(8)$ & $\mathrm{R}(8)$ \\
$99 \mathrm{I}$ & ad lib. $(8)$ & $\mathrm{R}(9)$ & $\mathrm{R}(8)$ & $\mathrm{R}+\mathrm{C}(8)$
\end{tabular}

Values in parentheses indicate number of weeks on treatment.

$\mathrm{R}=$ intake restricted to $70 \%$ of calculated appetite (see below); $+\mathrm{C}$ indicates presence of a rumen ciliate population.

In calculating the amount of feed offered during the periods of restricted intake, maximal intake was taken to be $100 \mathrm{~g} / \mathrm{kg}^{0.73}$ and the daily feed allowance was set at $70 \%$ of this amount $\left(70 \mathrm{~g} / \mathrm{kg}^{0.73}\right)$. This daily allowance was then adjusted weekly according to live weight. A daily intake amounting to less than $75 \%$ of maximal intake was recommended by Eadie et al. (1970) to ensure the development of rumen ciliates. In previous work (Eadie et al. 1970) maximal intake was taken to be $2.4 \%$ of live weight but later experience showed that this level progressively overestimated maximal intake at live weights in excess of $250 \mathrm{~kg}$. The present value, based on live weight ${ }^{0.73}$, was considered to be a more accurate estimate of voluntary intake over the weight range $25^{\circ}-55^{\circ} \mathrm{kg}$. In a recent study, Kay, Macdearmid \& MacLeod (1970) considered maximal intake to be equivalent to I $\%$ of empty body-weight ${ }^{0.73}$ and this 
value is almost identical to $100 \mathrm{~g} / \mathrm{kg}^{0.73}$ if the weight of gut contents is taken to be $10 \%$ of live weight.

Sampling procedures. Samples of rumen fluid for ciliate examination and volatile fatty acid (VFA) analysis were taken from each animal at Ir.oo hours on Tuesdays and Thursdays of each week throughout the experiment. In addition, during period 3 , fourteen samples were taken from each animal at regular intervals during a single $24 \mathrm{~h}$ period in order to examine changes in rumen $\mathrm{pH}$ and in VFA and ammonia concentration throughout the day. One week later, samples of venous blood were taken at $07.45,12.00$ and 16.00 hours on one day and were examined for haemoglobin, urea, glucose and free amino acids.

Rumen ciliate inocula. The mixed rumen ciliate inocula were prepared by concentrating the organisms from $500 \mathrm{ml}$ rumen fluid obtained from a cannulated cow given a mixed roughage-concentrate ration. The ciliates present in the inocula were Epidinium spp., Eudiplodinium maggii, Ostracodinium spp., Enoploplastron triloricatum, Eremoplastron spp., Entodinium spp., Isotricha spp. and Dasytricha ruminantium.

Microbial examination. Wet preparations of all rumen fluid samples were examined to assess the size and nature of the ciliate population or to determine, where relevant, that the animals were ciliate-free. Films prepared from formalin-fixed samples were stained by Gram's method and an assessment was made of the morphological forms of bacteria. Separate rumen samples were taken at intervals for viable counts of bacteria using the starch medium of Kurihara, Eadie, Hobson \& Mann (I968). An assessment of the bacterial types in these cultures was made by examination of smears made from colonies chosen at random. Total bacterial counts were also made on these samples using the Coulter Counter (Hobson \& Mann, 1970).

Rumen VFA and ammonia. Total VFA in rumen fluid were determined by steamdistillation in a Markham still and the $\mathrm{C}_{2}-\mathrm{C}_{6}$ acids, including the branched-chain isomers, were separated by gas-liquid chromatography as described by Fell, Kay, Whitelaw \& Boyne (1968). Rumen ammonia concentrations were measured by the method of Fawcett \& Scott (I960) using the Technicon AutoAnalyzer (Technicon Instruments Co. Ltd, Chertsey, Surrey). The $\mathrm{pH}$ of rumen fluid was determined electrometrically soon after withdrawal of samples from the rumen.

Blood and plasma analyses. Blood urea concentrations were measured on the Technicon AutoAnalyzer by the method of Marsh, Fingerhut \& Miller (1965). Blood haemoglobin levels were estimated by the method of Wootton (I964) using a commercial cyanmethaemoglobin standard (British Drug Houses Ltd, Poole, Dorset). The concentration of glucose in plasma was determined by the method of Huggett \& Nixon (1957) and the free amino acids in plasma were separated by a Technicon system using a $140 \times 0.6 \mathrm{~cm}$ column containing a cation exchange bead resin (Technicon Chromobeads ' $B$ '). The preparation of plasma samples for amino acid assay was according to Mechanic, Efron \& Shih (1966), with some minor modifications. 
Food intake and live-weight gain. During the ad lib. feeding period steer 857 had a very low voluntary intake and this animal did not fully consume its restricted daily ration until ro d after the period began. There were no further feed refusals by this animal. Steer 858 refused some food for ro d shortly before the $24 \mathrm{~h}$ series of rumen samples in period 3 and on the actual day on which these samples were taken. 'Throughout the periods of restricted feeding steers $99 \mathrm{I}$ and 977 ate their full ration.

All the steers showed increases of live weight over the period of restricted feeding. The older animals gained, on average, $72 \mathrm{~kg}$ in 18 weeks and the younger pair $82 \mathrm{~kg}$ in 25 weeks.

Ciliate populations. There were no rumen ciliate protozoa in the steers during the $a d l i b$. feeding period and the precautions against contamination of the ciliate-free animals proved adequate. Flagellate protozoa were seen intermittently in all the steers during the ciliate-free periods of restricted feeding. However, the only large populations seen coincided with periods of lowered intake and raised rumen $\mathrm{pH}$ in steers 857 and 858 .

Within I week of inoculation a large ciliate population had developed in steer 977 and persisted throughout the experiment. Similarly, in steer 857 a large ciliate population developed rapidly and in only three samples did the numbers fall to a level more typical of an animal given a $2: 1$ roughage-concentrate ration. In contrast, the numbers of ciliates in steer $99 \mathrm{I}$ during period 4 fluctuated considerably; in four samples a negligible population was seen and in two the numbers were equivalent to those in a roughage-concentrate-fed animal. In the remaining ten samples there were the very large populations typical of restricted barley feeding (Eadie et al. I970).

Members of the genera Entodinium, Epidinium and Eremoplastron were in the majority in the large populations. Though all the species from the inoculum were seen, neither Enoploplastron triloricatum nor Ostracodinium spp. persisted throughout the experiment in any of the animals and Eudiplodinium maggii was never seen in large numbers. Dasytricha ruminantium remained in steer 857 for 3 weeks following the inoculum but was not seen for longer than this in any of the other steers. Isotricha spp. were present in small numbers in all three inoculated animals.

Gram film examinations. The predominant organisms seen in Gram films during the ad lib. feeding period were bacteroides-type rods and Gram-positive cocci. This population is typical for adult animals given this diet.

During the restricted feeding periods there were no marked differences between Gram films from ciliate-free and from faunated animals. Gram-negative organisms of the bacteroides type were predominant under both conditions, but whereas these were mainly of the cocco-bacillus form in the faunated animals, there tended to be a larger number in the rod form in the absence of ciliates. Amongst the secondary types there was a more varied flora in the presence of ciliates with some small, negative cocci other than bacteroides type, various Gram-negative tetracocci and chains of Gram-variable organisms. The slender Gram-variable rod associated with the presence of ciliates (Eadie et al. 1970) was seen in all three faunated animals and 
reached high numbers on occasion. It was not seen in the absence of ciliates. Typical selenomonads were more often seen in the ciliate-free animals. In both ciliate-free and faunated animals Gram-positive cocci of the Streptococcus bovis form were frequently found in high numbers.

The Gram films from steer 858 on the day of the 24 h series of samples were atypical and showed a large number of Gram-positive rods. These organisms were not identified but did not appear to be lactobacilli. One week later the Gram film had reverted to the typical Gram-negative rod-cocco-bacillus picture.

The only other variations in Gram film picture which were noted were in samples from steer 99i. Bacteroides-type rods were seen to be predominant in one sample from period 2 , in which an exceptionally high ratio of propionic acid to butyric acid $(12.4: 1)$ was found. On the only occasion in this animal when butyric acid exceeded propionic in the absence of ciliates the atypical selenomonad (organism C; Eadie et al. 1970) was very conspicuous. The falls in ciliate number in steer 99I (period 4) were associated with large numbers of either the atypical selenomonad or the Gramnegative, vibrio-like rod (organisms $\mathrm{C}$ and $\mathrm{A}$ respectively; Eadie et al. 1970).

Bacterial types from culture. The predominant types seen in culture under ad lib. feeding conditions were bacteroides-type rods, Gram-positive rods (? Lactobacillus spp.), Gram-positive cocci (? Streptococcus bovis) and both typical and atypical selenomonads.

In the restricted periods of fceding, irrespective of the presence or absence of ciliates, the predominant organisms obtained in culture were Bacteroides spp. and slender, curved, negative rods (organisms A, B and C; Eadie et al. 1970). The fact that these curved rods were rarely amongst the predominant organisms seen on Gram-films from the same samples agrees with previous observations (Eadie et al. 1970).

Cultures from steer 858 on the day of the 24 h series of samples showed amongst the predominant organisms Gram-positive rods similar to those seen in the Gram films. This organism was also seen in fair numbers in cultures from steer $99 \mathrm{I}$ on the same day.

Bacterial numbers. The values for bacterial counts made during the ad lib. feeding period and at various stages in periods 2 and 3 are shown in Table 2 . There was a marked drop in viable count when the ration was restricted and both bacterial numbers and viable percentages were considerably reduced in the presence of ciliates. The rather high viable percentages obtained during the ciliate-free stages of the experiment confirm the observations of Eadie et al. (1970) that values for total bacterial counts obtained from barley-fed animals in the absence of ciliates may be lower than the true value. Thus it is difficult to comment on the changes in total count. The reason for the high values for both total and viable count in steer $99 \mathrm{I}, 8$ weeks after the restricted ration was introduced is not clear.

Rumen $p H$ and VFA. Mean values for rumen $\mathrm{pH}$, total VFA concentration and molar proportions of VFA in each treatment period are given for each animal in Table 3, except that because of poor intake the values for the $a d l i b$. period for steer 857 are omitted. The two samples during the week which immediately followed the inoculation with rumen ciliates were also omitted for steer 857 since it took longer to 
establish a typical large ciliate population in this animal than in the two smaller steers. Since there were no significant differences between animals or between periods in the molar proportions of isobutyric, isovaleric or caproic acids, these acids are presented in Table 3 as the sum of branched-chain plus higher acids. The mean values recorded were isobutyric $\mathrm{I} \cdot 94 \%$, isovaleric $2.90 \%$ and caproic $0.57 \%$.

In the three animals which consumed the barley diet $a d l i b$. the rumen $\mathrm{pH}$ values tended to be rather higher, and the total VFA concentrations generally lower, than is normally encountered under $a d$ lib. conditions. However, the rumen VFA proportions showed the typical low-acetic acid, high-propionic acid pattern previously described by Eadie et al. (1970) in cattle given barley ad lib. The ratio of propionic to

Table 2. Total and viable counts of rumen bacteria for four steers given an all-concentrate diet containing $85 \%$ barley

\begin{tabular}{|c|c|c|c|c|c|c|c|c|}
\hline \multirow[b]{2}{*}{ Period } & \multicolumn{2}{|c|}{ Steer 857} & \multicolumn{2}{|c|}{ Steer $85^{8}$} & \multicolumn{2}{|c|}{ Steer 977} & \multicolumn{2}{|c|}{ Steer $99 \mathrm{r}$} \\
\hline & $\begin{array}{c}\text { Total } \\
\left(\times 10^{-8} /\right. \\
\mathrm{ml})\end{array}$ & $\begin{array}{l}\text { Viable* } \\
\left(\times 10^{-9} / \mathrm{ml}\right)\end{array}$ & $\begin{array}{c}\text { Total } \\
(\times \text { ro } \\
\text { ml) }\end{array}$ & $\begin{array}{c}\text { Viable* } \\
\left(\times 10^{-9} / \mathrm{ml}\right)\end{array}$ & $\begin{array}{c}\text { Total } \\
\left(\times 10^{-9} /\right. \\
\mathrm{ml})\end{array}$ & $\begin{array}{c}\text { Viable* } \\
\left(\times_{10^{-8}} / \mathrm{ml}\right)\end{array}$ & $\begin{array}{l}\text { Total } \\
\left(\times \mathrm{ro}^{-9 /} /\right. \\
\mathrm{ml})\end{array}$ & $\begin{array}{c}\text { Viable* } \\
\left(\times 10^{-9} / \mathrm{ml}\right)\end{array}$ \\
\hline I: week 6 & 一 & - & 63.5 & II & $43 \cdot 9$ & $6 \cdot 30(14 \cdot 4)$ & $40 \cdot 4$ & $8.0($ I 97$)$ \\
\hline 2: week 6 & $22 \cdot 2$ & $3.5(15 \cdot 8)$ & $30 \cdot 7$ & $4.1(13 \cdot 4)$ & $43 \cdot I$ & $1 \cdot 60 \quad(3 \cdot 8)$ & $40 \cdot 9$ & $3.3 \quad(8 \cdot 0)$ \\
\hline 2: week 8 & $34^{\circ} 0$ & $3 \cdot I \quad(9 \cdot 2)$ & $20 \cdot 6$ & $777(37 \cdot 6)$ & $32 \cdot 7$ & $4.90\left(15^{\circ} 0\right)$ & $5 I \cdot 2$ & $16.9(330)$ \\
\hline 3 : week 3 & $14.7 \dagger$ & $0.5 \quad(3.6)$ & $26 \cdot 9$ & $I \cdot 9 \quad(7 \cdot I)$ & $13.2 \dagger$ & $0.04(0.3)$ & $28 \cdot 4$ & $10.5(37.0)$ \\
\hline 3: week 5 & $4-\pi \dagger$ & $0 \cdot 1 \quad(2 \cdot 5)$ & $26 \cdot 5$ & $I \cdot I \quad(4 \cdot 2)$ & $13.2 \dagger$ & $0.10 \quad(0.8)$ & $22 \cdot 0$ & $10.8\left(49^{\prime} \mathrm{r}\right)$ \\
\hline
\end{tabular}

Table 3. Rumen $p H$, total concentration and molar proportions of volatile fatty acids (VFA) in four steers given an all-concentrate diet containing $85 \%$ barley

(Mean values with their standard errors)

\begin{tabular}{|c|c|c|c|c|c|c|c|c|c|c|}
\hline \multirow[b]{2}{*}{$\begin{array}{c}\text { Animal } \\
\text { no. }\end{array}$} & \multirow[b]{2}{*}{ Period } & \multirow[b]{2}{*}{$\begin{array}{l}\text { Dietary } \\
\text { treat- } \\
\text { ment }\end{array}$} & \multirow[b]{2}{*}{$\begin{array}{l}\text { No. of } \\
\text { samples }\end{array}$} & \multirow[b]{2}{*}{$\begin{array}{l}\text { fumen } \\
\text { es } \mathrm{pH}\end{array}$} & \multirow[b]{2}{*}{$\begin{array}{c}\text { Total } \\
\text { VFA } \\
(\mathrm{mmol} / \mathrm{l})\end{array}$} & \multicolumn{5}{|c|}{ Molar proportions of VFA (\%) } \\
\hline & & & & & & Acetic & Propionic & Butyric & Valeric & $\begin{array}{l}\text { Branched- } \\
\text { chain }+ \\
\text { higher } \\
\text { acids }\end{array}$ \\
\hline \multirow[t]{3}{*}{857} & I & ad lib. & - & - & 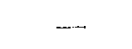 & - & - & $\longrightarrow$ & - & - \\
\hline & 2 & & 15 & $5^{6} \cdot 6 \pm 0 \cdot I$ & $I 43 \pm 4$ & $53 \pm \mathrm{r} \cdot 3$ & $25 \pm 2 \cdot 0$ & $14 \pm x \cdot 7$ & $2 \pm 0.2$ & $5 \pm 0.4$ \\
\hline & 3 & $R+C$ & 16 & $6.2 \pm 0.1$ & $123 \pm 4$ & $60 \pm 0.9$ & $15 \pm 0.9$ & $19 \pm 0.5$ & \pm 0.1 & $4 \pm 0 \cdot 1$ \\
\hline \multirow[t]{3}{*}{$8_{5} 8$} & I & ad lib. & 6 & $5.9 \pm 0.1$ & $12 I \pm 5$ & $43 \pm I \cdot 4$ & $34 \pm 1 \cdot 6$ & $13 \pm x \cdot 3$ & $5 \pm 0.5$ & $4 \pm 0 \cdot 6$ \\
\hline & 2 & $\mathrm{R}$ & 17 & $5.4 \pm 0.1$ & $161 \pm 2$ & $49 \pm 0.4$ & $35 \pm 0.4$ & $8 \pm 0.2$ & $3 \pm 0.2$ & $5 \pm 0.2$ \\
\hline & 3 & $\mathrm{R}$ & 18 & $5 \cdot 7 \pm 0.1$ & $148 \pm 6$ & $48 \pm I \cdot 8$ & $29 \pm 2 \cdot 0$ & ${ }^{I} 3 \pm I \cdot 7$ & $4 \pm 0.5$ & $6 \pm 0.4$ \\
\hline \multirow[t]{4}{*}{977} & I & ad lib. & 3 & $5.4 \pm 0.1$ & $I 40 \pm 5$ & $39 \pm I \cdot 4$ & $39 \pm r \cdot 8$ & $12 \pm 0.7$ & $7 \pm 2 \cdot 0$ & $3 \pm 0.7$ \\
\hline & 2 & & 18 & $5 \cdot 6 \pm 0.1$ & $122 \pm 5$ & $56 \pm I \cdot 6$ & $24 \pm x \cdot 8$ & I $1 \pm 0.6$ & $2 \pm 0.1$ & $7 \pm 0.4$ \\
\hline & 3 & $\mathrm{R}+\mathrm{C}$ & I6 & $6 \cdot 7 \pm 0.1$ & $85 \pm 4$ & $6_{3} \pm 0.4$ & $13 \pm 0.3$ & $18 \pm 0.4$ & $2 \pm 0.1$ & $4 \pm 0.2$ \\
\hline & 4 & $\mathbf{R}+\mathbf{C}$ & 16 & $6 \cdot 4 \pm 0 \cdot x$ & $108 \pm 4$ & $60 \pm 0.6$ & I I \pm 0.4 & $21 \pm 0.5$ & $2 \pm 0.1$ & $6 \pm 0 \cdot 3$ \\
\hline \multirow[t]{4}{*}{$99 \mathrm{I}$} & I & $a d l i b$. & 3 & $5 \cdot 5 \pm 0 \cdot 1$ & $127 \pm 4$ & $35 \pm 0.8$ & $3 x \pm 2 \cdot 7$ & $22 \pm 1 \cdot 4$ & $7 \pm 2 \cdot 2$ & $5 \pm I \cdot 2$ \\
\hline & 2 & $\mathrm{R}$ & 18 & $5 \cdot 3 \pm 0-1$ & I $46 \pm 4$ & $47 \pm I \cdot 3$ & $32 \pm 1 \cdot 2$ & $\mathrm{I} 3 \pm I \cdot I$ & $3 \pm 0.2$ & $5 \pm 0.3$ \\
\hline & 3 & $\mathrm{R}$ & 16 & $5.6 \pm 0.1$ & $145 \pm 3$ & $47 \pm 1 \cdot 5$ & $28 \pm 1 \cdot 2$ & $15 \pm 1 \cdot 6$ & $3 \pm 0.1$ & $7 \pm 0.4$ \\
\hline & 4 & & 16 & $5.9 \pm 0.1$ & $125 \pm 4$ & $50 \pm 1 \cdot 8$ & $19 \pm 2 \cdot 2$ & $2 I \pm I \cdot I$ & $3 \pm 0.4$ & $7 \pm 0.6$ \\
\hline
\end{tabular}

$\mathbf{R}=$ intake restricted to $70 \%$ of calculated appetite (see p. 426 ); $+\mathrm{C}$ indicates presence of a rumen ciliate population. 
butyric acid (P:B ratio) in these animals ranged from $I \cdot 9$ to 3.6 during the period of ad lib. intake.

In all animals, restriction of feed intake resulted in rumen $\mathrm{pH}$ values and VFA concentrations similar to those encountered under ad lib. feeding conditions. The major changes in VFA proportions on restriction of intake were an increase in acetic acid and a decrease in valeric acid. Propionic and butyric acids in general showed only minor changes and gave rise to mean $P: B$ ratios ranging from $I \cdot 8$ to $4 \cdot 4$. These ratios, however, tended to narrow in steers 858 and 99I when these animals were subjected to a further period of restricted feeding under ciliate-free conditions; in $85^{8}$ the mean ratio decreased from 4.4 to 2.2 , and in $99 \mathrm{I}$ from 2.5 to 1.9 , in progressing from period 2 to period 3 .

During the ciliate-free periods the proportion of butyric acid exceeded that of propionic acid on only two occasions, once in 858 and once in 991 . In each instance the altered fermentation pattern persisted for only $3-4 \mathrm{~d}$ and appeared to be associated with a change in the bacterial flora of the rumen; in 858 the change occurred at the time of the $24 \mathrm{~h}$ series of samples (see p. 429 and Table 5 ) and in $99 \mathrm{I}$ the high butyrate fermentation coincided with the presence of large numbers of the atypical selenomonad in the rumen contents (see p. 429).

In steers 857 and 977 the establishment of ciliate protozoa in the rumen in period 3 resulted in an increase in rumen $\mathrm{pH}$ and a reduction in total VFA concentration relative to their cilate-free pair-mates. The presence of ciliates resulted also in a marked alteration in VFA proportions: acetic and butyric acids increased while propionic acid decreased to values between I $\mathrm{I}$ and $15 \%$. In consequence, mean $\mathrm{P}: \mathrm{B}$

Table 4. Rumen $p H$, total concentration and molar proportions of volatile fatty acids $(V F A)$ in steer $99 \mathrm{I}$ in the presence of large, moderate and negligible rumen ciliate populations

(Mean values with their standard errors)

\begin{tabular}{|c|c|c|c|c|c|c|c|c|}
\hline \multirow[b]{2}{*}{$\begin{array}{c}\text { Ciliate } \\
\text { population }\end{array}$} & \multirow[b]{2}{*}{$\begin{array}{l}\text { No. of } \\
\text { samples }\end{array}$} & \multirow[b]{2}{*}{$\begin{array}{c}\text { Rumen } \\
\mathrm{pH}\end{array}$} & \multirow[b]{2}{*}{$\begin{array}{c}\text { Total } \\
\text { VFA } \\
\text { (mmol/1) }\end{array}$} & \multicolumn{5}{|c|}{ Molar proportions of VFA $(\%)$} \\
\hline & & & & Acetic & Propionic & Butyric & Valeric & $\begin{array}{c}\text { Branched- } \\
\text { chain }+ \\
\text { higher } \\
\text { acids }\end{array}$ \\
\hline Large & 10 & $6.03 \pm 0.06$ & $120 \pm 4$ & $54 \pm 0.7$ & $14 \pm I \cdot 0$ & $24 \pm 0.5$ & $2 \pm 0.2$ & $6 \pm 0 \cdot 3$ \\
\hline Moderate* & 2 & $5.85 \pm 0.1 \mathrm{I}$ & $122 \pm 9$ & $50 \pm 0.1$ & $2, \pm 0.3$ & $18 \pm 0.6$ & $3 \pm 0.6$ & $8 \pm 0 \cdot 2$ \\
\hline Negligible & 4 & $5 \cdot 62 \pm 0.23$ & $139 \pm 8$ & $39 \pm 3 \cdot 0$ & $31 \pm 4 \cdot 3$ & $16 \pm 1.9$ & $5 \pm 0.8$ & $9 \pm I \cdot 7$ \\
\hline
\end{tabular}

* Equivalent to a typical population in a roughage-concentrate-fed animal.

ratios were less than unity, ranging from 0.52 to 0.73 in different periods. In only three individual samples did the $P: B$ ratio slightly exceed unity and these were the samples from steer 857 in which a reduced cilate population had been noted (see p. 428). It was noticeable that the variability from sample to sample in the molar proportion of each acid tended to be lower during the periods in which ciliates were present than in the ciliate-free periods.

The change in mean rumen $\mathrm{pH}$ and the alteration in mean VFA proportion in 
response to ciliate inoculation was much less marked in steer $99 \mathrm{r}$ (period 4 ) than in the two other steers. As noted earlier, however (p. 428), the ciliate population in this animal was less stable than in the others and showed marked fluctuations in number during the latter half of the 8-week period. Microscopic examination of all samples taken during this period showed that they fell into three distinct categories with regard to the size of the ciliate population. Rumen $\mathrm{pH}$ and VFA values based on our assessment of ciliate population (p. 428) are shown in Table 4 , from which it can be seen that changes in ciliate populations were associated with progressive changes in rumen $\mathrm{pH}$, total VFA concentration and $\mathrm{P}: \mathrm{B}$ ratio.

Changes in rumen $\mathrm{pH}$ and in total VFA concentration during the $24 \mathrm{~h}$ sampling period are shown for steers 977 and $99 \mathrm{I}$ in Fig. I. These results indicate a consistently higher $\mathrm{pH}$ and lower total VFA concentration in the presence of ciliates throughout the daily feeding cycle and confirm the findings observed during the major treatment periods. This is true also, in these two animals, of the mean VFA proportions throughout $24 \mathrm{~h}$ (Table 5 ).

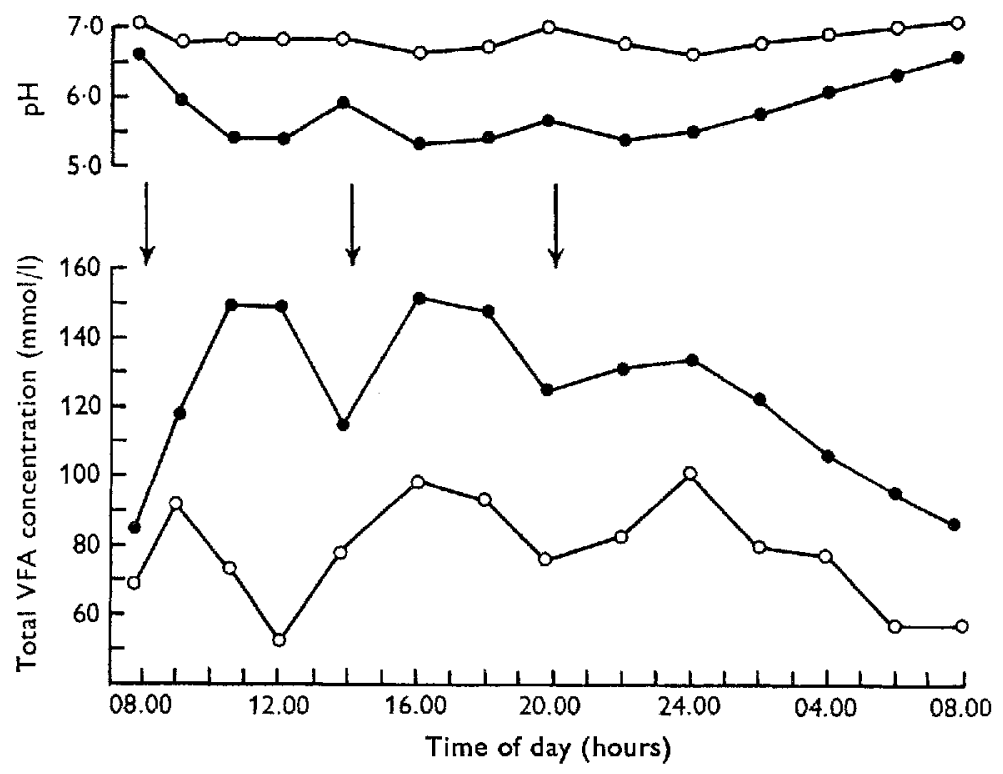

Fig. $\mathrm{I}$. Changes in rumen $\mathrm{pH}$ and in total volatile fatty acid (VFA) concentration throughout a $24 \mathrm{~h}$ period in steers $977(\mathrm{O}-\mathrm{O})$ and $99 \mathrm{I}(-)$ given an all-concentrate diet containing $85 \%$ barley at a restricted level of intake. Steer 977 had a large population of rumen ciliates; steer $99 \mathrm{I}$ was ciliate-free. Times of feeding are indicated by arrows.

In steer 857 , the pattern of change in rumen $\mathrm{pH}$ and VFA concentration during the 24 h period was identical to that recorded in steer 977 , and VFA proportions showed the usual low-propionic acid, high-butyric acid picture (Table 5 ). In steer 858 , however, a completely anomalous fermentation pattern was recorded during the $24 \mathrm{~h}$ period; the rumen VFA contained a very high proportion of butyric acid and a low proportion of propionic acid and the values were quite unlike those recorded for this animal throughout the rest of period 3. As noted earlier, this animal had undergone 
a period of depressed appetite shortly before this $24 \mathrm{~h}$ experiment and it also failed to consume its full feed allowance on the day in question. Although unusually large numbers of a Gram-positive rod were present both in cultures and in Gram films from this animal at this time (p. 429), there is insufficient evidence to link this organism with the alteration in VFA pattern. This organism was present in smaller numbers in cultures from steer $99 \mathrm{r}$ on the same day but appeared to have no effect on VFA proportions.

Table 5. Rumen $p H$, total concentration and molar proportions of volatile fatty acids $(V F A)$ throughout $a 24 h$ period in four steers given restricted amounts of an all-concentrate diet containing $85 \%$ barley

(Mean values with their standard errors)

\begin{tabular}{cccccccc} 
Animal & \multicolumn{3}{c}{ Molar proportions of VFA (\%) } \\
no. & Rumen pH & $\begin{array}{c}\text { Total VFA } \\
(\mathrm{mmol} / \mathrm{l})\end{array}$ & Acetic & Propionic & Butyric & Valeric & $\begin{array}{c}\text { Branched- } \\
\text { higher acids }\end{array}$ \\
$857^{*}$ & $6.56 \pm 0.04$ & $96 \pm 3$ & $62 \pm 0.5$ & $9 \pm 0.3$ & $23 \pm 0.3$ & $2 \pm 0.1$ & $4 \pm 0.2$ \\
$85^{8}$ & $5.50 \pm 0.04$ & $165 \pm 3$ & $42 \pm 1.2$ & $15 \pm 0.5$ & $34 \pm 0.9$ & $2 \pm 0.1$ & $7 \pm 0.3$ \\
$977^{*}$ & $6.86 \pm 0.04$ & $78 \pm 4$ & $63 \pm 0.3$ & $13 \pm 0.4$ & $17 \pm 0.2$ & $2 \pm 0.1$ & $5 \pm 0.2$ \\
991 & $5.80 \pm 0.12$ & $123 \pm 6$ & $42 \pm 0.9$ & $27 \pm 0.3$ & $19 \pm 0.9$ & $4 \pm 0.1$ & $8 \pm 0.2$
\end{tabular}

* Rumen ciliate population present.

Table 6. Plasma glucose, blood urea, blood haemoglobin and plasma amino acid concentrations in four steers given restricted amounts of an all-concentrate diet containing $85 \%$ barley

\begin{tabular}{|c|c|c|c|c|}
\hline \multicolumn{5}{|c|}{ (Mean values with their standard errors) } \\
\hline & Steer $857^{*}$ & Steer $85^{8}$ & Steer $977^{*}$ & Steer 991 \\
\hline $\begin{array}{l}\text { Plasma glucose }(\mathrm{mg} / \mathrm{r} 00 \mathrm{ml}) \\
\text { Blood urea }(\mathrm{mg} / \mathrm{ro0} \mathrm{ml}) \\
\text { Blood haemoglobin }(\mathrm{g} / \mathrm{ro0} \mathrm{ml})\end{array}$ & $\begin{array}{l}76 \cdot 1 \pm 1 \cdot 3 \\
27 \cdot 7 \pm 0 \cdot 3 \\
10 \cdot 5 \pm 0 \cdot 3\end{array}$ & $\begin{array}{l}83 \cdot 8 \pm 0 \cdot 3 \\
22 \cdot 0 \pm 0 \cdot 7 \\
12 \cdot 0 \pm 0 \cdot 0\end{array}$ & $\begin{array}{l}73 \cdot 7 \pm 1 \cdot 3 \\
29 \cdot 4 \pm 0.6 \\
10.0 \pm 0.4\end{array}$ & $\begin{array}{l}87 \cdot 1 \pm 0 \cdot 7 \\
2 I \cdot I \pm I \cdot I \\
I I \cdot 2 \pm 0 \cdot 3\end{array}$ \\
\hline $\begin{array}{l}\text { Plasma amino acids }(\mathrm{mg} / 100 \mathrm{~m} \\
\text { o7.45 hours } \\
\text { Essentialt } \\
\text { Total }\end{array}$ & $\begin{array}{l}\text { I } 5.73 \\
29.68\end{array}$ & $\begin{array}{l}16 \cdot \text { I I } \\
30 \cdot 04\end{array}$ & $\begin{array}{l}14.92 \\
26.85\end{array}$ & $\begin{array}{l}15 \cdot 36 \\
31 \cdot 13\end{array}$ \\
\hline $\begin{array}{l}\text { I6.0o hours } \\
\text { Essential } \\
\text { Total }\end{array}$ & $\begin{array}{l}11.75 \\
23.64\end{array}$ & $\begin{array}{l}12 \cdot 17 \\
24 \cdot 57\end{array}$ & $\begin{array}{l}\text { II } 30 \\
23 \cdot 40\end{array}$ & $\begin{array}{l}14 \cdot 96 \\
28 \cdot 08\end{array}$ \\
\hline
\end{tabular}

* Rumen ciliate population present.

+ Threonine, valine, methionine, lysine, leucine, isoleucine, phenylalanine, histidine, arginine.

The mean concentrations of ammonia in rumen liquor throughout the $24 \mathrm{~h}$ period were $\mathrm{I}_{3} \cdot 2 \pm \mathrm{I} \cdot 4$ (SE) and $\mathrm{I} 2 \cdot 3 \pm \mathrm{I} \cdot 6 \mathrm{mg} \mathrm{NH} \mathrm{NH}_{3}-\mathrm{N} / \mathrm{r} 00 \mathrm{ml}$ rumen fluid for steers 977 and 99 I respectively. Although there was no significant difference between these animals in the mean daily $\mathrm{NH}_{3}$ concentrations, the patterns of $\mathrm{NH}_{3}$ production throughout the day were distinctly different and were similar to those reported previously for faunated and ciliate-free cattle (Eadie et al. 1970). Steer 857 showed the same pattern of $\mathrm{NH}_{3}$ production as did 977 , with a mean concentration of $I 3.5 \pm \mathrm{I} \cdot \mathrm{I} \mathrm{mg} / \mathrm{I} 00 \mathrm{ml}$, but, as 
for the VFA values, steer 858 showed a completely anomalous pattern, the concen-

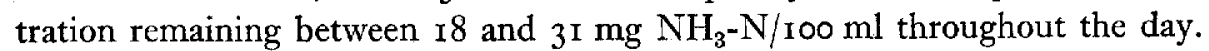

Blood and plasma analyses. Mean values for plasma glucose, blood urea and blood haemoglobin concentrations in three samples of blood taken at 07.45 hours, 12.00 hours and 16.00 hours on one day are given for each animal in Table 6 , together with values for plasma amino acids at 07.45 hours and 16.00 hours on the same day. Plasma glucose concentrations were significantly lower $(P<0.01)$ and blood urea concentrations were significantly higher $(P<0 \cdot 01)$ in each faunated animal than in its unfaunated pair-mate. Blood haemoglobin concentrations were also consistently lower in the faunated animals but the difference reached significance $(P<0.05)$ only within the older pair of animals.

The concentrations of both total and essential amino acids in plasma were significantly lower $(P<0.05)$ at $\mathbf{I} 6.00$ hours than at 07.45 hours but did not differ between faunated and non-faunated animals. Of the individual amino acids examined, only valine, histidine and ornithine showed a response to treatment, each of these being significantly lower $(P<0.01)$ in the faunated animals.

\section{DISCUSSION}

The major object in these experiments was to examine rumen fermentation in the presence or absence of ciliate protozoa in cattle given restricted amounts of a pelleted barley diet. In our earlier work (Eadie et al. 1970), restriction of intake in the absence of ciliates appeared to lead to an increase in rumen $\mathrm{pH}$ relative to that with ad lib. intake and it was suggested that this initial change in $\mathrm{pH}$ was a prerequisite to the eventual establishment of ciliates. This suggestion has not been borne out in the present experiments, since rumen $\mathrm{pH}$ values during the restricted ciliate-free periods were similar to those commonly observed on ad lib. intake (Eadie et al. 1970). Despite this low $\mathrm{pH}$, ciliates were established with ease after a single inoculation. While the $\mathrm{pH}$ values reported here for restricted intake were probably close to the minimum values of the day (see Fig. I), this was true also of the samples taken from the steers in our earlier work. The reason for this discrepancy between the two experiments is not known.

Since ciliates have never been successfully established under conditions of ad lib. intake of this diet (Eadie, Hobson \& Mann, 1967), it would appear that the survival of ciliates is dependent on both the duration and extent of any depression in $\mathrm{pH}$, rather than on minimum $\mathrm{pH}$ alone, as has been suggested previously (Purser $\&$ Moir, I959; Eadie, 1962). Thus the particular feature of our restricted feeding schedule which allowed the establishment of ciliates was probably the overnight, food-free period, in which rumen $\mathrm{pH}$ showed a steady increase to values in excess of 6.5 (Fig. $\mathrm{r}$ ). Though evidence is available that rumen $\mathrm{pH}$ under conditions of ad lib. intake can also fluctuate considerably and can be above 6.5 (Eadie et al. 1967; Fell et al. 1968), these periods of elevated $\mathrm{pH}$ seem to persist for only $2-3 \mathrm{~h}$ and are frequently followed by a precipitous decrease.

The general concentrations and proportions of rumen VFA observed under re- 
stricted, ciliate-free conditions were almost identical to those normally found when the barley diet is given ad lib. (Eadie $e t$ al. I970). Apart from a slight tendency for mean $\mathrm{pH}$ to increase and mean $\mathrm{P}: \mathrm{B}$ ratio to decrease in the ciliate-free animals in progressing from period 2 to period 3 , there was no evidence of any long-term adaptative response to restricted intake. Although there was a reduction in bacterial numbers and certain changes in bacterial types in response to the restriction of intake, the resultant population was basically similar to that in the faunated animals with respect to the predominant types found in culture.

The rumen conditions in the faunated steers in these experiments were similar to those reported by Eadie et al. (1970) for comparable animals given restricted amounts of the same diet. As before, the major changes relative to the ciliate-free state were an increase in $\mathrm{pH}$, a reduction in total VFA concentration and a pronounced decrease in the ratio of propionic to butyric acid in rumen fluid. In every instance these changes were coincident with the establishment of large ciliate populations and, with the exception of steer 991, conditions within the rumen tended thereafter to be more stable both from day to day and throughout a single $24 \mathrm{~h}$ period than they were during the earlier, ciliate-free periods or in the ciliate-free control animals. Since there was no gross change in bacterial types as seen in culture, there is thus prima facie evidence that the ciliates were directly responsible for the alterations in rumen fermentation.

As in the previous work of Eadie et al. (1970), the only ciliate genera to develop in significant numbers from the original mixed inoculum were Entodinium, Epidinium and Eremoplastron. Members of these genera have already been noted to be associated with the production of butyric rather than propionic acid in vitro (Eadie et al. 1970; Eadie \& Mann, I970). The ability of ciliates to ingest dietary starch and the possible effects of this activity on rumen fermentation have been discussed by Oxford (1955) and more recently by Whitelaw, Hyldgaard-Jensen, Reid \& Kay (1970), who related changes in ciliate numbers to observed differences in the rates of VFA production in faunated barley-fed cattle.

The changes in rumen VFA proportion associated with the fluctuation in ciliate numbers in steer 99I were similar to those reported in the heifers used in our earlier work (Eadie et al. 1970). No explanation can be offered for the sudden onset of unstable conditions in this steer, since a large ciliate population became established rapidly after inoculation and gave rise to a typical high-butyrate fermentation mixture which remained stable for almost 4 weeks. Thereafter there was no obvious change in intake pattern or in any other factor which might have resulted in a reduction in ciliate numbers. Similarly, although the decreases in ciliate number were associated with changes in the bacterial flora as seen on Gram films, there was no suggestion of any radical change in bacterial species which might have accounted for the alteration in fermentation pattern. The occurrence of spontaneous changes in the rumen microbial populations of barley-fed cattle has been discussed by Eadie \& Mann (1970).

Although the results of the present work and of our earlier study indicate that the presence of ciliates leads to a major alteration in rumen VFA proportions in cattle fed on barley, only minor and inconsistent changes in VFA pattern have been observed between ciliate-free and faunated sheep given traditional roughage-concentrate diets 
(Abou Akkada \& El-Shazly, r964; Christiansen, Kawashima \& Burroughs, I965; Klopfenstein, Purser \& Tyznik, I966; Luther, Trenkle \& Burroughs, I966; Eadie \& Gill, 1971). It should be noted, however, that the rumen ciliate populations with these traditional diets tend to be small relative to those encountered with the barley diet (Eadic et al. 1970 ) and the proportionate contribution of the ciliates to the overall fermentation process probably differs widely between the two dietary regimens. In a recent study of faunated and ciliate-free sheep given mixed diets, Eadie \& Gill (1971) suggested that the small differences they detected in rumen VFA were as likely to result from observed changes in bacterial flora as from the activity of ciliates. Similar reservations could probably be applied to many of the earlier findings which have been ascribed to the presence of ciliates.

Conflicting reports are also available regarding the effects of a rumen ciliate population on the concentrations of various metabolites in the blood of sheep (Abou Akkada \& El-Shazly, 1965; Klopfenstein et al. 1966; Eadie \& Gill, 1971). As indicated above, a strict comparison between these findings in sheep and the present results for barley-fed cattle is probably unwarranted. In the present work the increased concentration of glucose in the plasma of the ciliate-free steers appeared to be directly related to the higher concentrations of propionic acid in the rumens of these animals. Similarly, the differences recorded for blood urea concentrations can probably be explained by reference to rumen ammonia concentration (Lewis, 1957), which tended to be higher in the presence of ciliates during that part of the day in which the blood samples were taken (Eadie et al. 1970). No ready explanation can be offered, however, for the small but consistent differences noted in blood haemoglobin concentrations. The effect of ciliates on plasma amino acid concentration would appear to warrant further study in view of the direct conflict between the present findings and those reported in sheep by Klopfenstein et al. (1966) and Purser, Klopfenstein \& Cline (I966).

As mentioned above, a lowering of the ratio of propionic to butyric acid in rumen fluid as a consequence of the establishment of ciliates has been a consistent feature only in cattle given an all-grain, roughage-free diet. In a recent report, however, Ishaque, Thomas \& Rook (197I) described a low-propionic acid, high-butyric acid fermentation in sheep given a diet containing $24 \%$ ground hay together with barley and flaked maize and indicated that this fermentation pattern could be altered to a high-propionic type by some poorly defined manipulation of the feeding schedule. Although no information was given on the microbiology of the rumen, the changes in rumen ammonia concentration under these conditions were characteristic of the changes normally induced by a reduction in the ciliate population. Though there is no evidence that ciliates played any part in these reactions, the subsequent demonstration by these workers that the type of fermentation in the rumen can influence the composition of digesta reaching the duodenum has an obvious bearing on the practical significance of our experiments. 
We are indebted to Dr R. N. B. Kay for performing the rumen fistulations, to $\mathrm{Mr}$ W. Hepburn for amino acid analyses and to Miss Carol Grant, Mr A. H. Faulks and

$\mathrm{Mr}$ W. Shand for technical assistance.

\section{REFERENCES}

Abou Akkada, A. R. \& El-Shazly, K. (1964). Appl. Microbiol. 12, 384.

Abou Akkada, A. R. \& El-Shazly, K. (r965). F. agric. Sci., Camb. 64, 25 I.

Christiansen, W. C., Kawashima, R. \& Burroughs, W. (1965). F. Anim. Sci. 24, 730.

Eadie, J. M. (1 962). F. gen. Microbiol. 29, 563.

Eadie, J. M. \& Gil1, J. C. (I97 I). Br. \%. Nutr. 26, I55.

Eadie, J. M., Hobson, P. N. \& Mann, S. O. (I967). Anim. Prod. 9, 247.

Eadie, J. M., Hyldgaard-Jensen, J., Mann, S. O., Reid, R. S. \& Whitelaw, F. G. (1970). Br. Y. Nutr. 24, I57.

Eadie, J. M. \& Mann, S. O. (1970). In Physiology of Digestion and Metabolism in the Ruminant p. 335 [A. T. Phillipson, editor]. Newcastle upon Tyne: Oriel Press Ltd.

Fawcett, J. K. \& Scott, J. E. (1960). F. clin. Path. r3, 156.

Fell, B. F., Kay, M., Whitelaw, F. G. \& Boyne, R. (1968). Res. vet. Sci. 9, $45^{8}$.

Hobson, P. N. \& Mann, S. O. (1970). In Automation, Mechanization and Data Handling in Microbiology p. 91 [A. Baillie and R. J. Gilbert, editors]. London: Academic Press.

Tuggett, A. St G. \& Nixon, D. A. (1957). Lancet ii, 368 .

Ishaque, M., Thomas, P. C. \& Rook, J. A. F. (1971). Proc. Nutr. Soc. 3o, I A.

Kay, M., Macdearmid, A. \& MacLeod, N. A. (1970). Anim. Prod. 12, 26r.

Klopfenstein, T. J., Purser, D. B. \& Tyznik, W. J. (1966). J. Anim. Sci. 25, 765.

Kurihara, Y., Eadie, J. M., Hobson, P. N. \& Mann, S. O. (I968). F. gen. Microbiol. 5I, 267.

Lewis, D. (1957). F. agric. Sci., Camb. 48, $43^{8}$.

Luther, R., Trenkle, A. \& Burroughs, W. (1966). F. Anim. Sci. 25, I 16.

Marsh, W. H., Fingerhut, B. \& Miller, H. (1965). Clin. Chem. rr, 624.

Mechanic, G., Efron, M. L. \& Shih, V. E. (1966). Analyt. Biochem. 16, 420.

Oxford, A. E. (1955). F. Sci. Fd Agric. 6, 413.

Purser, D. B., Klopfenstein, T. J. \& Cline, J. H. (1966). F. Nutr. 89, 226.

Purser, D. B. \& Moir, R. J. (1959). Aust. F. agric. Res. ro, 555.

Whitelaw, F. G., Hyldgaard-Jensen, J., Reid, R. S. \& Kay, M. G. (r970). Br. F. Nutr, $24,179$.

Wootton, I. D. P. (1964). Micro-analysis in Medical Biochemistry 4 th ed. p. I I9. London: J. and A. Churchill Ltd. 